\title{
Processos e poéticas na criação de personagens: reflexões em gravura
}

\section{Luciana Vasconcelos MACÊDO}

\section{Resumo}

O tema deste projeto é o estudo das possibilidades poéticas e estéticas do processo de criação de personagens através do uso de técnicas de impressão em gravura. Trata-se de uma pesquisa em arte, o que implica que sua orientação é feita a partir da própria produção. A obra fornecerá o suporte ao redor da qual será construído o discurso teórico. A pesquisa será feita a partir da construção de uma história, tomando como referências os contos-de-fadas tradicionais, em cujo contexto estará inserida a personagem. Tais referências literárias foram escolhidas por seu caráter lúdico e seu teor fantástico, embora seja necessário ressaltar que a história será apenas esboçada, pois não é o foco da pesquisa. A base da pesquisa é prática, através da busca constante de uma experimentação consciente das técnicas e uma constante reflexão sobre como os elementos visuais resultantes dos processos de impressão produzem significados e influem em sua leitura. Os problemas centrais da pesquisa podem ser definidos como: quais seriam os resultados de uma incursão no processo de criação de personagem em que todas as potencialidades poéticas da gravura (calcogravura, litogravura, serigrafia, xilogravura e também processos híbridos) fossem utilizadas para dar vida e voz a uma personagem? Quais seriam as relações da personagem com seu ambiente, e com o ambiente do observador? Como se constrói o discurso emocional em torno de uma personagem de contos de fada, e como suas características visuais podem expressar esse discurso? O objetivo desta pesquisa, finalmente, é a criação de um jogo de reflexão com base nos resultados dos processos de impressão, através das especificidades do trabalho do artista gravador.

Palavras-chave: Gravura, ilustração, poéticas visuais. 